\title{
PERILAKU KEWARGAAN ORGANISASI (ORGANIZATIONAL CITIZENSHIP BEHAVIOR) SEBAGAI FAKTOR YANG MEMPENGARUHI KINERJA PEGAWAI
}

\section{ORGANIZATIONAL CITIZENSHIP BEHAVIOR AS A FACTOR AFFECTING EMPLOYEE PERFORMANCE}

\author{
Deviandra Sandhika, Ade Sobandi \\ Email: deviandra.sandhika94@student.upi.edu; ade@upi.edu.
}

\begin{abstract}
ABSTRAK
Kinerja pegawai merupakan salah satu kunci keberhasilan suatu organisasi. Setiap organisasi selalu berusaha meningkatkan kinerja pegawai untuk mencapai tujuan. Tujuan organisasi akan tercapai jika organisasi dapat mengoptimalkan kinerja para pegawainya. Perilaku kewargaan organisasi merupakan salah satu faktor yang telah terbukti secara empiris memiliki pengaruh yang signifikan terhadap kinerja. Artikel ini membahas hasil penelitian yang ditujukan untuk mengetahui pengaruh diantara kedua variabel tersebut. Objek penelitian ini adalah sub bagian dari suatu instansi kedinasan di Kota Bandung. Penelitian menggunakan metode survey eksplanasi, kemudian data dikumpulkan dengan cara menyebarkan kuesioner yang dikembangkan dengan model skala likert kepada 27 orang pegawai. Hasil analisis menunjukkan bahwa perilaku kewargaan organisasi (organizational citizenship behavior) dan kinerja pegawai berada pada kondisi cukup baik, dan perilaku kewargaan organisasi (organizational citizenship behavior) memiliki pengaruh positif terhadap kinerja pegawai. Untuk meningkatkan keterkaitan pengaruh diantara dua variabel, hubungan sesama rekan kerja harus terus diperbaiki sehingga lingkungan kerja sosial yang terbangun dapat secara maksimal mendukung kinerja karyawan.
\end{abstract}

Kata Kunci: Perilaku Kewargaan Organisasi, Kinerja Pegawai

\section{PENDAHULUAN}

Bagi setiap organisasi penilaian kinerja merupakan suatu kegiatan yang sangat penting. Penilaian kinerja merupakan faktor kunci dalam mengembangkan potensi pegawai secara efektif dan efisien karena adanya kebijakan atau program yang lebih baik atas sumberdaya manusia yang ada di dalam suatu organisasi.

Prestasi atau kinerja adalah catatan tentang hasil-hasil yang diperoleh dari fungsifungsi pekerjaan tertentu atau kegiatan selama kurun waktu tertentu. Kinerja maupun prestasi kerja mengandung substansi pencapaian hasil kerja oleh seseorang. Dengan demikian bahwa kinerja maupun prestasi kerja merupakan cerminan hasil yang dicapai oleh seseorang atau sekelompok orang, seperti yang diungkapkan Bernardin dan Russel (Ruky, 2002, hlm. 15).

Kinerja ini kemudian menjadi sorotan bagi organisasi pemerintahan dalam mengartikulasikan hal-hal apa saja yang dapat menunjang bagi peningkatan kinerja sehingga terciptanya keunggulan bersaing yang berkelanjutan atau dikenal dengan istilah sustainable competitive advantage.

Borman dan Motowidlo (Novliadi 2007, hlm 6) mengungkapkan bahwa organizational citizenship behavior dapat meningkatkan kinerja organisasi (organizational 
performance) karena perilaku ini merupakan "pelumas" dari mesin sosial dalam organisasi, dengan kata lain dengan adanya perilaku ini maka interaksi sosial pada anggota-anggota organisasi menjadi lancar, mengurangi terjadinya perselisihan, dan meningkatkan efisiensi.

Organizational citizenship behavior menurut Organ dalam Podsakoff et al. (2000, hlm. 513), bahwa organizational citizenship behavior merupakan suatu perilaku individu yang tidak diatur oleh organisasi, dan yang tidak diperhitungkan sistem reward secara formal, namun perilaku ini akan mendorong efektivitas dan efisiensi fungsi organisasi secara keseluruhan. Perilaku tersebut meliputi: mempelajari tugas-tugas baru, sebagai sukarelawan yang melakukan sesuatu bagi keuntungan kelompok, dan lebih memiliki orientasi terhadap karyawan baru.

Namun terkadang ada beberapa faktor-faktor yang menghambat pegawai melakukan perilaku kewargaan organisasi (organizational citizenship behavior) sehingga kinerja pegawai tidak efektif dan efisien sebagaimana yang diharapkan. Misalnya seperti yang terjadi pada kinerja pegawai salah satu unit kerja di sebuah instansi kedinasan Kota Bandung ini, yakni sebagai berikut:

Gambar 1

Rata-Rata Penilaian Prestasi Kerja Pegawai

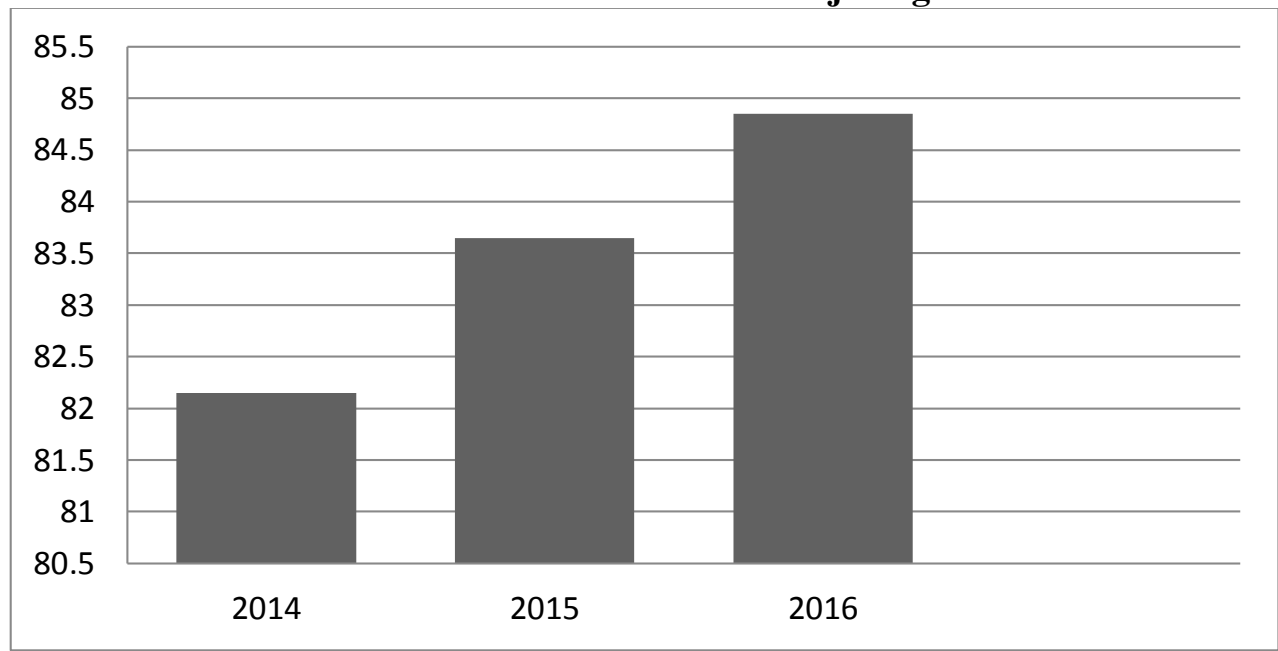

Sumber: Rekapitulasi Penilaian Prestasi Kerja Pegawai Sub Bagian Umum dan Kepegawaian Dinas Pendidikan Kota Bandung

Gambar di atas merupakan data penilaian prestasi kerja pegawai dalam 3 tahun terakhir. Untuk lebih jelas mengetahui sejauh mana pencapaian kinerja atau prestasi kerja pegawai, data di atas dapat di konversi dengan skala penilaian prestasi kerja di bawah ini

Tabel 1

Skala Penilaian Prestasi Kerja

\begin{tabular}{|c|c|c|}
\hline Nilai & Kriteria Nilai & Keterangan \\
\hline A & $90-100$ & Sangat Baik \\
\hline B & $80-89$ & Baik \\
\hline C & $60-79$ & Cukup Baik \\
\hline D & $40-59$ & Buruk \\
\hline E & $20-39$ & Sangat Buruk \\
\hline
\end{tabular}

Sumber: PERKA BKN NO 1 TAHUN 2013 
Berdasarkan data yang tertuang dalam gambar 1 di atas dapat dilihat, capaian ratarata penilaian prestasi kerja pegawai menunjukan proses yang positif. Hal ini ditunjukkan dengan meningkatnya capaian prestasi kerja pegawai pada tiap tahunnya. Namun dalam nilai kenaikan dari tahun sebelumnya mengalami penurunan. Kemudian permasalahan lainnya dapat dilihat dari data gambar 1, masih belum mencapai target yang diharapkan yakni mencapai predikat "sangat baik", karena nilai capaian tertinggi berada pada tahun 2016 dengan nilai sebesar 84,85 yang diartikan masih dalam kriteria nilai B "baik" berdasarkan skala penilaian prestasi kerja pada tabel 1. Dari data yang tertuang dalam gambar 1, prestasi kerja unit kerja tersebut dalam 3 tahun terakhir hanya mencapai predikat "baik".

Belum maksimalnya kinerja pegawai ini merupakan suatu masalah, terlebih karena unit kerja berada dalam instansi kedinasan yang secara langsung maupun tidak langsung memiliki kewajiban memberikan pelayanan terbaik. Sehingga kurang maksimalnya kinerja pegawai akan berdampak pada kurang maksimalnya kualitas pelayanan, apabila hal ini terus dibiarkan, tentu akan merugikan banyak pihak.

Salah satu upaya untuk memecahkan permasalahan di atas salah satunya adalah dengan meningkatkan perilaku kewargaan organisasi (organizational citizenship behavior). Hal ini sejalan dengan apa yang dikemukakan oleh Borman dan Motowidlo dalam Novliadi (2007, hlm 6) yang menyatakan bahwa "organizational citizenship behavior dapat meningkatkan kinerja organisasi (organizational performance) karena perilaku ini merupakan "pelumas" dari mesin sosial dalam organisasi, dengan kata lain dengan adanya perilaku ini maka interaksi sosial pada anggota-anggota organisasi menjadi lancar, mengurangi terjadinya perselisihan, dan meningkatkan efisiensi".

Artikel ini menyajikan hasil penelitian yang ditujukan untuk mengetahui bagaimana pengaruh perilaku kewargaan organisasi (organizational citizenship behavior) terhadap kinerja pegawai, yang bertujuan untuk mengetahui secara detail faktor yang masih harus ditingkatkan dari perilaku kewargaan organisasi (organizational citizenship behavior) sehingga kinerja pegawai menjadi maksimal. Berikut adalah pemaparan beberapa teori yang berkaitan variabel yang diteliti, bagaimana data dikumpulkan, dianalisis dan diinferensi sehingga mencapai kesimpulan yang menjadi temuan dari penelitian yang dilakukan.

\section{Tinjauan Pustaka}

\section{Perilaku Kewargaan Organisasi (Organizational Citizenship Behavior)}

Organisasi harus percaya bahwa untuk mencapai keunggulannya, perlu mengusahakan kinerja individu yang setinggi-tingginya. Pada dasarnya kinerja individu mempengaruhi kinerja tim dan pada akhirnya mempengaruhi kinerja organisasi secara keseluruhan. Perilaku yang menjadi tuntutan organisasi tidak hanya perilaku in-role tetapi juga perilaku extra-role. Perilaku extra-role sangat penting artinya karena memberikan manfaat yang lebih baik untuk menunjang keberlangsungan organisasi. Perilaku extra-role di dalam organisasi dikenal dengan istilah Organizational Citizenship Behavior (Oguz, 2010, hlm. 1188). Menurut Organ (Podsakoff et al., 2000, hlm. 513), bahwa Organizational Citizenship Behavior merupakan suatu perilaku individu yang tidak diatur oleh organisasi, dan yang tidak diperhitungkan sistem reward secara formal, namun perilaku ini akan mendorong efektivitas dan efisiensi fungsi organisasi secara keseluruhan. Perilaku tersebut meliputi: mempelajari tugas-tugas baru, sebagai sukarelawan yang melakukan sesuatu bagi keuntungan kelompok, dan lebih memiliki orientasi terhadap karyawan baru.

Fakta yang menunjukkan bahwa organisasi yang mempunyai karyawan yang memiliki Organizational Citizenship Behavior (OCB) yang baik, akan memiliki kinerja yang lebih baik dari organisasi lain (Robbins dan Judge, 2008 hlm. 40). Terkait indikator 
perilaku kewargaan organisasi (organizational citizenship behavior), Organ dalam Herminingsih (2012, hlm. 128-129), berpendapat bahwa perilaku citizenship atau ekstra peran ini diimplementasikan dalam 5 bentuk perilaku, yaitu:
a. Altruism (perilaku membantu orang lain).
b. Conscientiousness (ketelitian dan kehati-hatian atau kedisiplinan).
c. Sportmanship (perilaku yang sportif).
d. Countesy (menjaga hubungan baik).
e. Civic virtue (kebijaksanaan pekerja).

Altruism merupakan sifat mementingkan kepentingan orang lain, seperti memberikan pertolongan pada kawan sekerja yang baru, dan menyediakan waktu untuk orang lain. Dimensi ini mengarah kepada memberi pertolongan yang bukan merupakan kewajiban yang ditanggungnya.

Conscientiousness merupakan sifat kehati-hatian seperti efisiensi menggunakan waktu, dan tingkat kehadiran tinggi. Perilaku ini berusaha untuk melebihi yang diharapkan oleh perusahaan atau perilaku yang sukarela yang bukan merupakan kewajiban atau tugas karyawan.

Sportmanship adalah dengan memaksimalkan total jumlah waktu yang dipergunakan pada usaha-usaha yang konstruktif dalam organisasi. Perilaku yang memberikan toleransi terhadap keadaan yang kurang ideal dalam organisasi tanpa mengajukan keberatankeberatan. Sportmanship akan meningkatkan iklim yang positif diantara karyawan, karyawan akan lebih sopan dan bekerja sama dengan yang lain, sehingga akan menciptakan lingkungan kerja yang lebih menyenangkan.

Countesy merupakan menjaga hubungan baik dengan rekan kerja agar terhindar dari masalah-masalah interpersonal. Seseorang yang memiliki dimensi ini adalah orang yang menghargai dan memperhatikan orang lain, seperti: sifat sopan dan taat terhadap rekan kerja maupun kepada atasan sekalipun.

Civic virtue merupakan perilaku yang mengindikasikan tanggungjawab pada kehidupan organisasi, seperti mengikuti perubahan dalam organisasi, mengambil inisiatif untuk merekomendasikan bagaimana operasi atau prosedur-prosedur organisasi dapat diperbaiki, dan melindungi sumber-sumber yang dimiliki oleh organisasi. Dimensi ini mengarah kepada tanggungjawab yang diberikan organisasi kepada seseorang untuk meningkatkan kualitas bidang pekerjaan yang ditekuninya.

\section{Kinerja Pegawai}

Kinerja adalah prestasi kerja atau hasil kerja (output) baik kualitas maupun kuantitas yang dicapai pegawai persatuan periode waktu dalam melaksanakan tugas kerjanya sesuai dengan tanggung jawab yang diberikan kepadanya (Mangkunegara, 2009 hlm. 9). Kemudian Sedarmayanti (2009 hlm. 259) mengemukakan bahwa kinerja adalah hasil kerja yang dicapai oleh seseorang atau kelompok dalam organisasi, sesuai dengan wewenang dan tanggung jawab masing-masing, dalam rangka upaya mencapai tujuan organisasi bersangkutan secara legal, tidak melanggar hukum dan sesuai dengan moral maupun etika.

Kinerja dapat didefinisikan sebagai tingkat pencapaian seseorang secara keseluruhan selama periode tertentu Moeheriono dalam Yulianingsih, Tresna Lia dan A. Sobandi (2017 hlm. 52). Secara lebih spesifik, Bernardin dan Russel dalam Ruky (2002, hlm. 15) mengemukakan Performance is defined as the record of outcomes produced on a specified job function or activity during time period. Prestasi atau kinerja adalah catatan tentang hasilhasil yang diperoleh dari fungsi-fungsi pekerjaan tertentu atau kegiatan selama kurun waktu tertentu. Kinerja maupun prestasi kerja mengandung substansi pencapaian hasil kerja 
oleh seseorang. Dengan demikian bahwa kinerja maupun prestasi kerja merupakan cerminan hasil yang dicapai oleh seseorang atau sekelompok orang.

Terkait indikator kinerja pegawai, Bernardin dan Russel dalam Sutrisno (2010, hlm. 179-180) mengajukan enam kinerja primer yang dapat digunakan untuk mengukur kinerja, yaitu: kualitas (quality), kuantitas (quantity), batas waktu kerja (timeliness), efektivitas biaya (cost effectiveness), kebutuhan pengawasan (need for supervision), interpersonal impact.

Kualitas kerja adalah tingkat sejauh mana proses atau hasil pelaksanaan kegiatan mendekati kesempurnaan atau mendekati tujuan yang diharapkan. Kemudian kuantitas kerja merupakan jumlah yang dihasilkan. misalnya jumlah rupiah, unit, dan siklus kegiatan yang dilakukan. Batas waktu kerja adalah sejauh mana suatu kegiatan diselesaikan pada waktu yang dikehendaki, dengan memperhatikan koordinasi output lain serta waktu yang tersedia untuk kegiatan orang lain. Lalu efektivitas biaya merupakan tingkat sejauh mana penggunaan sumber daya organisasi (manusia, keuangan, teknologi, dan material) dimaksimalkan untuk mencapai hasil tertinggi atau pengurangan kerugian dari setiap unit penggunaan sumber daya. Kebutuhan pengawasan merupakan tingkat sejauh mana seorang pekerja dapat melaksanakan suatu fungsi pekerjaan tanpa memerlukan pengawasan seorang supervisi untuk mencegah tindakan yang kurang diinginkan. Interpersonal impact, merupakan tingkat sejauh mana pegawai memelihara harga diri, nama baik, dan kerjasama di antara rekan kerja dan bawahan.

Dari uraian tentang perilaku kewargaan organisasi (organizational citizenship behavior) dan kinerja pegawai di atas, dapat diambil kesimpulan bahwa perilaku kewargaan organisasi (organizational citizenship behavior) memiliki peran penting dalam mempengaruhi kinerja pegawai. Menurut Aldag dan Reschke (1997, hlm. 4), organizational citizenship behaviors sebagai kontribusi individu yang sangat besar melebihi tuntutan peran di organisasi dan menjadikan pencapaian kinerja yang sangat baik. Dengan begitu maka berdasarkan tinjauan pustaka di atas, dapat digambarkan theoretical framework seperti tampak pada gambar berikut:

\section{Gambar 2}

Theoretical Framework

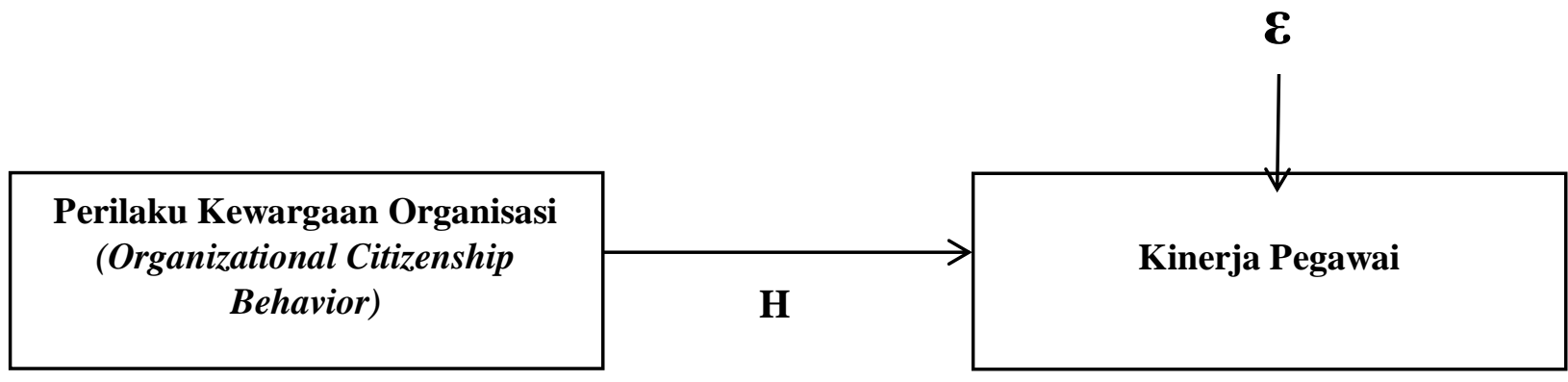

Dari theoretical framework tersebut, penelitian ini memiliki hipotesis yaitu:

$\mathrm{H}=$ terdapat pengaruh perilaku kewargaan organisasi (organizational citizenship behavior) terhadap kinerja pegawai.

\section{METODOLOGI PENELITIAN}

Untuk menjawab permasalahan yang menjadi fokus penelitian, penulis menggunakan metode penelitian survey eksplanasi. Respondennya adalah para pegawai salah satu unit kerja di instansi kedinasan Kota Bandung, yang berjumlah 27 orang dan 
merupakan populasi dalam penelitian ini. Teknik pengumpulan data menggunakan kuesioner dengan model skala likert yang terdiri dari dua bagian. Bagian pertama adalah angket untuk mengukur persepsi responden mengenai perilaku kewargaan organisasi (organizational citizenship behavior), yang dijabarkan menjadi 9 indikator yaitu selalu siap memberi bantuan pada orang-orang yang ada di sekelilingnya, secara sengaja, tulus, dan spontan menolong orang yang terlihat membutuhkan bantuan, melaksanakan pekerjaan sesuai dengan prosedur, menunjukkan perilaku yang melebihi dari prasyarat minimum, dapat dengan mudah beradaptasi dengan lingkungan kerja, selalu menunjukkan semangat dan antusiasme dalam bekerja, berusaha untuk menghargai dan menjaga hubungan baik dengan orang lain, mempunyai rasa memiliki pada organisasi di mana dia bekerja, dan menginginkan adanya kemajuan bagi organisasi, yang terdiri dari 19 item. Bagian kedua adalah angket untuk mengukur persepsi responden mengenai kinerja yang dijabarkan menjadi 6 indikator yaitu kualitas (quality), kuantitas (quantity), batas waktu kerja (timelines), efektivitas biaya (cost effectiviness), kebutuhan pengawasan (need for supervision), dan interpersonal impact, yang terdiri dari 13 item

Teknik analisis yang digunakan adalah analisis deskriptif dan analisis inferensial. Analisis deskriptif menggunakan persentase frekuensi yang digunakan untuk memperoleh gambaran tingkat persepsi responden mengenai perilaku kewargaan organisasi (organizational citizenship behavior) dan kinerja pegawai. Sedangkan pada analisis inferensial menggunakan teknik analisis regresi sederhana yang digunakan untuk menguji hipotesis dan koefisiensi determinasi untuk mengukur besarnya pengaruh perilaku kewargaan organisasi (organizational citizenship behavior) dalam model regresi terhadap kinerja pegawai.

\section{HASIL PENELITIAN DAN PEMBAHASAN \\ Perilaku Kewargaan Organisasi (Organizational Citizenship Behavior)}

Hasil analisis deskriptif secara umum pada variabel perilaku kewargaan organisasi (organizational citizenship behavior) menunjukkan skor sedang dengan rata-rata skor sebesar 2.68. Ini menunjukkan menurut persepsi responden mengenai perilaku kewargaan organisasi (organizational citizenship behavior) berada pada kategori sedang. Tabel dibawah ini menyajikan skor rata-rata persentase dari masing-masing indikator yang dijadikan ukuran perilaku kewargaan organisasi (organizational citizenship behavior). 
Tabel 2

Deskripsi Perilaku Kewargaan Organisasi (Organizational Citizenship Behavior)

\begin{tabular}{|c|c|c|c|}
\hline Indikator & Item & $\begin{array}{l}\text { Rata- } \\
\text { rata }\end{array}$ & Penafsiran \\
\hline $\begin{array}{l}\text { Selalu siap memberi bantuan pada orang-orang yang ada } \\
\text { di sekelilingnya }\end{array}$ & $1-2$ & 2.80 & Sedang \\
\hline $\begin{array}{c}\text { Secara sengaja, tulus, dan spontan menolong orang yang } \\
\text { terlihat membutuhkan bantuan }\end{array}$ & $3-4$ & 2.50 & Rendah \\
\hline Melaksanakan pekerjaan sesuai dengan prosedur & $5-6$ & 2.35 & Rendah \\
\hline $\begin{array}{c}\text { Menunjukkan perilaku yang melebihi dari prasyarat } \\
\text { minimum }\end{array}$ & $7-8$ & 2.73 & Sedang \\
\hline $\begin{array}{c}\text { Dapat dengan mudah beradaptasi dengan lingkungan } \\
\text { kerja }\end{array}$ & $9-11$ & 2.81 & Sedang \\
\hline $\begin{array}{l}\text { Selalu menunjukkan semangat dan antusiasme dalam } \\
\text { bekerja }\end{array}$ & 12 & 2.56 & Rendah \\
\hline $\begin{array}{c}\text { Berusaha untuk menghargai dan menjaga hubungan } \\
\text { baik dengan orang lain }\end{array}$ & $13-14$ & 2.57 & Rendah \\
\hline $\begin{array}{l}\text { Mempunyai rasa memiliki pada organisasi di mana dia } \\
\text { bekerja }\end{array}$ & $15-16$ & 2.95 & Sedang \\
\hline Menginginkan adanya kemajuan bagi organisasi & 17.00 & 2.89 & Sedang \\
\hline \multicolumn{2}{|l|}{ Rata-rata } & 2.68 & Sedang \\
\hline
\end{tabular}

Sumber: Hasil Pengolahan Data

Skor tertinggi berada pada indikator mempunyai rasa memiliki pada organisasi di mana dia bekerja yaitu sebesar 2.95 dengan kategori sedang. Sedangkan skor terendah berada pada indikator melaksanakan pekerjaan sesuai dengan prosedur dengan rata-rata persentase sebesar 2.35 atau berada pada kategori rendah. Sehingga skor rata-rata pada variabel perilaku kewargaan organisasi (organizational citizenship behavior) sebesar 2.68 atau berada pada kategori sedang.

\section{Kinerja Pegawai}

Hasil analisis deskriptif secara umum pada variabel kinerja pegawai menunjukkan skor sedang dengan rata-rata skor sebesar 2.61. Ini menunjukkan menurut persepsi responden mengenai kinerja pegawai berada pada kategori sedang. Tabel dibawah ini menyajikan skor rata-rata persentase dari masing-masing indikator yang dijadikan ukuran kinerja pegawai. 
Tabel 3

Deskripsi Kinerja Pegawai

\begin{tabular}{l|c|c|l}
\hline \multicolumn{1}{c|}{ Indikator } & Item & $\begin{array}{c}\text { Rata- } \\
\text { rata }\end{array}$ & \multicolumn{1}{c}{ Penafsiran } \\
\hline Kualitas (Quality) & $1-2$ & 2.39 & Kurang baik \\
\hline Kuantitas (Quantity) & $3-4$ & 2.63 & Cukup baik \\
\hline Batasan Waktu Kerja (Timelines) & $5-7$ & 2.84 & Cukup baik \\
\hline Efektivitas Biaya (Cost Effectiviness) & 8 & 2.56 & Kurang baik \\
\hline Kebutuhan Pengawasan (Need for Supervision) & $9-12$ & 2.8 & Cukup baik \\
\hline Interpersonal Impact & 13 & 2.44 & Kurang baik \\
\hline Rata-rata & & $\mathbf{2 . 6 1}$ & Cukup baik \\
\hline
\end{tabular}

Sumber: Hasil Pengolahan Data

Skor tertinggi berada pada indikator batas waktu kerja yaitu sebesar 2.84 dengan kategori cukup baik. Sedangkan skor terendah berada pada indikator kualitas dengan ratarata sebesar 2.39 atau berada pada kategori kurang baik. Sehingga skor rata-rata pada variabel perilaku kewargaan organisasi (organizational citizenship behavior) sebesar 2.61 atau berada pada kategori cukup baik.

Hasil penghitungan analisis regresi sederhana dari variabel perilaku kewargaan organisasi (organizational citizenship behavior) terhadap kinerja pegawai adalah $b=0.482$, $a=12.7662$, maka dapat dirumuskan persamaan regresi sebagai berikut:

$$
\hat{\mathrm{Y}}=a+b \mathrm{X}
$$

Kinerja pegawai $=12.7662+0.482 \mathrm{x}$

Berdasarkan persamaan regresi ini dapat dilihat bahwa nilai $b$ menunjukkan tanda positif, maka diinterpretasikan bahwa setiap peningkatan perilaku kewargaan organisasi (organizational citizenship behavior) maka akan diikuti pula dengan meningkatnya kinerja pegawai. Untuk hasil uji koefisien regresi sederhana antara variabel lingkungan kerja sosial terhadap kinerja karyawan, dengan taraf kepercayaan pada penelitian ini sebesar $95 \%$ atau $a=0,05$, adalah sebagai berikut:

Tabel 1

Hasil Uji t Data Hipotesis

\begin{tabular}{|c|c|}
\hline Keterangan & Nilai \\
\hline $\mathrm{t}_{\text {tabel }}$ & 2.060 \\
\hline $\mathrm{t}_{\text {hitung }}$ & 3.276 \\
\hline
\end{tabular}

Sumber: Hasil olah data instrumen (2017)

Dari tabel di atas dapat diketahui bahwa hasil $\mathrm{t}_{\text {hitung }}>\mathrm{t}_{\text {tabel }}=3.276>2.060$. Dengan ini hipotesis penelitian "terdapat pengaruh perilaku kewargaan organisasi (organizational citizenship behavior) terhadap kinerja pegawai" diterima. Maka dapat ditarik kesimpulan bahwa terdapat pengaruh signifikan perilaku kewargaan organisasi (organizational citizenship behavior) terhadap kinerja pegawai di unit kerja instansi pemerintahan. Adapun untuk hasil penghitungan koefisien determinasi adalah sebesar 18\%. Dari hasil tersebut, dapat diketahui bahwa besarnya pengaruh perilaku kewargaan organisasi (organizational citizenship behavior) terhadap kinerja pegawai adalah sebesar $18 \%$, sedangkan sisanya $82 \%$ 
dipengaruhi oleh faktor-faktor lainnya. Dengan demikian, keseluruhan hasil menunjukkan bahwa perilaku kewargaan organisasi (organizational citizenship behavior) memiliki pengaruh yang positif dan signifikan terhadap kinerja pegawai.

\section{KESIMPULAN DAN SARAN \\ Kesimpulan}

Perilaku kewargaan organisasi (organizational citizenship behavior) yang meliputi indikator selalu siap memberi bantuan pada orang-orang yang ada di sekelilingnya, secara sengaja, tulus, dan spontan menolong orang yang terlihat membutuhkan bantuan, melaksanakan pekerjaan sesuai dengan prosedur, menunjukkan perilaku yang melebihi dari prasyarat minimum, dapat dengan mudah beradaptasi dengan lingkungan kerja, selalu menunjukkan semangat dan antusiasme dalam bekerja, berusaha untuk menghargai dan menjaga hubungan baik dengan orang lain, mempunyai rasa memiliki pada organisasi di mana dia bekerja, dan menginginkan adanya kemajuan bagi organisasi berada pada kategori cukup baik. Pada variabel Perilaku kewargaan organisasi (organizational citizenship behavior), indikator mempunyai rasa memiliki pada organisasi di mana dia bekerja yaitu sebesar 2.95 dengan kategori sedang. Sedangkan skor terendah berada pada indikator melaksanakan pekerjaan sesuai dengan prosedur dengan rata-rata sebesar 2.35 atau berada pada kategori rendah. Sedangkan pada variabel kinerja pegawai yang diukur melalui indikator kuantitas kerja, batas waktu kerja, dan kebutuhan pengawasan, berada pada kategori cukup baik. Kemudian, indikator kualitas, efektivitas biaya, dan interversonal impact berada pada kategori kurang baik. Pada variabel kinerja pegawai, batas waktu kerja memiliki skor tertinggi, dan indikator kualitas kerja memiliki skor terendah. Hasil penelitian menyimpulkan bahwa perilaku kewargaan organisasi (organizational citizenship behavior) berpengaruh terhadap kinerja pegawai secara positif dan signifikan.

Dengan demikian, penulis menawarkan rekomendasi kepada para pemangku kepentingan dan pembuat kebijakan dalam rangka memaksimalkan kinerja karyawan. Instansi pemerintahan perlu meningkatkan perilaku kewargaan organisasi (organizational citizenship behavior) diantaranya dengan cara mempererat kekeluargaan di dalam organisasi sehingga akan timbul sikap perhatian dan saling membantu, serta untuk merubah pola pikir tentang pentingnya bekerja sesuai dengan prosedur yang berlaku supaya kualitas dan akurasi kerja lebih baik lagi, meningkatkan sikap pentingnya saling membantu antar pegawai, pekerja dituntut agar melaksanakan kerja sesuai prosedur, dan meningkatkan semangat pekerja.. 


\section{Daftar Pustaka}

A.A. Anwar Prabu Mangkunegara. 2009. Manajemen Sumber Daya Manusia. Bandung: PT. Remaja Rosdakarya.

Aldag R.,and Reschke, W. 1997. Employee Value Added: Measuring Discretionary Effort and Its Value. Center for Organization Effectiveness, 1-8.

Herminingsih, Anik. 2012. Spiritualitas dan Kepuasan Kerja sebagai Faktor Organizational Citizenship Behavior (OCB). Jurnal Ilmu Ekonomi dan Sosial, Jilid 1, Nomor 2, hlm. 126-140

Novliadi, Ferry. 2007. Organizational Citizenship Behavior Karyawan Ditinjau dari Persepsi terhadap Kualitas Interaksi Antara Atasan-Bawahan dan Persepsi terhadap Dukungan Organisasi. Makalah Psikologi bagi Tenaga Akademik maupun Nonakademik di Lingkungan Universitas Sumatera Utara, Medan, 30 Agustus 2007.

Oguz. 2010. The Relation Between The Leadership Style of The School Administrators and The Organizational Citizenship Behaviors of Teacher. Procedia Social and Behavioral Sciences 9, 1188-1193

Podsakoff, P.M.; MacKenzie, S.B.; Paine, J.B.; dan Bachrach, D.G. 2000. Organizational Citizenship Behavior : Critical Review of The Theoretical and Empirical Literature and Suggestions for Future Research. Journal of Management, 26 (3) : 513 - 563.

Robbins dan Judge. 2008. Perilaku Organisasi, buku 1, cetakan 12. Jakarta: Salemba Empat.

Ruky, Ahmad. 2002. Sistem Manajemen Kinerja. Jakarta : Gramedia Pustaka Utama

Sedarmayanti. 2009. Manajemen Sumber Daya Manusia: Reformasi Birokrasi dan Manajemen Karyawan Negeri Sipil. Bandung: Refika Aditama.

Sutrisno, Edy. 2010. Manajemen Sumber Daya Manusia. Jakarta: Kencana Prenada Media Group.

Yulianingsih, Tresna Lia, dan A. Sobandi. 2017. Kinerja Mengajar Sebagai Faktor Determinan Prestasi Belajar Siswa. Jurnal Pendidikan Manajemen Perkantoran: Vol.1_no.1_hal. 50-57_JULI 2017 